\title{
Twenty Four
}

National Cancer Institute

\section{Source}

National Cancer Institute. Twenty Four. NCI Thesaurus. Code C113753.

A natural number greater than twenty-three and less than twenty-five and the quantity that it denotes. 